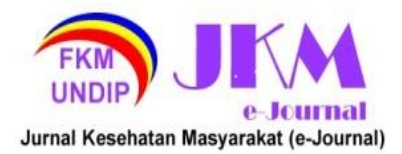

JURNAL KESEHATAN MASYARAKAT (e-Journal)

Volume 10, Nomor 1, Januari 2022

ISSN: 2715-5617 / e-ISSN: 2356-3346

http://ejournal3.undip.ac.id/index.php/ikm

\title{
DESAIN TEMPAT KERJA BERBASIS ENGINEERING CONTROL SEBAGAI PENGENDALIAN COVID-19
}

\author{
Ajeng Fitria Utami ${ }^{*}$ \\ ${ }^{1}$ Jurusan Ilmu Kesehatan Masyarakat, Fakultas Ilmu Keolahragaan, Universitas Negeri Semarang \\ *Corresponding author: ajengfitriautami@students.unnes.ac.id
}

\begin{abstract}
The current COVID-19 pandemic has had a negative impact on the world of work, one of which is the informal industry. To protect informal workers from exposure to COVID-19, control efforts can be carried out through the UKK Post from the Puskesmas, one of which is by developing an engineering control-based workplace design that is in accordance with ISO/PAS 45005:2020. Design of this research is Research and Development Level 1, using instruments in the form of questionnaires, interview guidelines, and validation sheets. The sample in this study was the Head of the UKK Post and the UKK Pos UKK cadre at Puskesmas X with the sampling technique being purposive sampling, and 3 validators. The results of the research conducted indicate that the development of workplace designs carried out is the development of ventilation, room layout, floor signs or markers, and physical barriers in the administrative, production and finishing areas. Workplace design development products that have been made get grades in a decent category with minor improvements based on the validation carried out with the validators.
\end{abstract}

Keywords: COVID-19, development, work place

\section{PENDAHULUAN}

Latar Belakang

Saat ini dunia sedang dihadapkan dengan pandemi COVID-19. Di Indonesia, selama 6 bulan terakhir dari bulan September 2020 sampai dengan bulan Februari 2021 mengalami kenaikan sebesar $35 \%$ pada setiap bulannya. Sedangkan di Jawa Barat, dalam rentang bulan September 2020 sampai dengan bulan Februari 2021 setidaknya terjadi kenaikan kasus terkonfirmasi COVID-19 sebesar 63\% setiap bulannya. Dan di Kota Bekasi kenaikan kasus terkonfirmasi COVID-19 yang terjadi sebesar $78 \%$ setiap bulannya. Dengan tingginya kasus COVID-19 yang terjadi saat ini berdampak negatif bagi dunia pekerjaan, salah satunya sektor informal. Pekerja informal merupakan pekerja uang paling rentan terhadap penularan COVID-19, karena mereka banyak berinteraksi dengan orang luar dan sulit mematuhi protocol kesehatan. Pekerja sektor informal juga tidak memiliki perlindungan kesehatan serta lingkungan kerja yang baik. ${ }^{1}$ Menurut ILO ${ }^{2}$, pekerja informal yang diperkirakan sebanyak $61 \%$ dari total pekerja di dunia merupakan pekerja yang paling rentan terhadap risiko keselamatan kerja dan proteksi terhadap COVID-19. Dengan demikian, maka perlu adanya upaya yang dapat melindungi para pekerja informal dari risiko penularan COVID-19 di tempat kerja. Salah satu upaya yang dapat dilakukan adalah dengan memfasilitasi pekerja informal dengan membentuk Pos UKK. Salah satu Pos UKK yang terdapat di Kota Bekasi adalah Pos UKK Puskesmas X yang berada di Kecamatan Bekasi Selatan. Berdasarkan studi pendahuluan yang dilakukan oleh penulis, belum ada upaya intervensi pada para pekerja di Pos UKK terkait COVID-19. Berdasarkan Keputusan
Menteri Kesehatan RI Nomor HK.01.07/Menkes/328/2020 Tentang Panduan Pencegahan dan Pengendalian COVID-19 di Tempat Kerja Perkantoran dan Industri dalam Mendukung Keberlangsungan Usaha pada Situasi Pandemi dan ISO/PAS 45005:2020 terdapat beberapa upaya pengendalian COVID-19 yang dapat dilakukan di tempat kerja, salah satunya dengan menerapkan pengendalian COVID-19 berdasarkan Hirarki Pengendalian, salah satunya adalah rekayasa teknik atau engineering control.

Salah satu upaya dalam penerapan engineering control adalah mendesain ulang tempat kerja. Berdasarkan penelitian yang dilakukan oleh Vischer \& Wifi, $^{24}$ kualitas pekerjaan dapat dipengaruhi oleh desain tempat kerja dan lingkungan kerja yang baik karena pekerja dapat menempati ruangan kerja yang disesuaikan dengan berbagai pengaturan meja dan kursi serta pencahayaan yang sesuai dengan jenis pekerjaan sehingga dapat meningkatkan konsentrasi dalam melakukan pekerjaan. Sedangkan, berdasarkan penelitianyang dilakukan oleh Siregar, ${ }^{25}$ mendesain ulang tempat kerja juga dapat memperlancar proses alur pekerjaan guna meningkatkan produktivitas kerja.

Masalah yang ada adalah sebagian besar tempat kerja mengatur tempat kerja dengan jarak yang berdekatan antara satu pekerja dengan pekerja lainnya sehingga membuat virus COVID-19 mudah meyebar. ${ }^{18}$ Maka dari itu perlunya mendesai ulang tempat kerja sesuai dengan protokol kesehatan yang ada. 


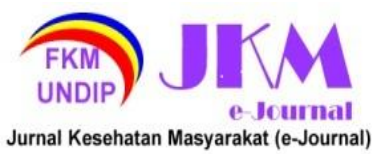

\section{Landasan Teori}

Pengendalian dan pencegahan COVID-19 di tempat kerja berdasarkan Hirarki Pengendalian adalah sebagai berikut:

Eliminasi. Upaya ini belum bisa dilakukan karena bahaya kerja (virus) belum dapat dihilangkan. ${ }^{3}$

Substitusi, upaya ini juga belum bias dilakukan karena bahaya kerja atau vorus belum dapat diganti saat tempat kerja dibuka kembali ${ }^{3}$.

Rekayasa Teknik, upaya yang dilakukan menurut ILO ${ }^{3}$ dapat berupa pengaturan ulang terhadap tata letak ruang kerja, pemasangan tanda atau rambu seperti stiker berwarna di lantai dengan jarak 1-2 meter untuk menunjukan dimana pekerja harus berdiri dan duduk, pemasangan penghalang fisik/physical barrier di meja kerja, dan pertimbangan untuk mengembangkan ventilasi di dalam ruangan baik ventilasi alami maupun mekanik.

Administrasi, upaya yang dapat dilakukan meliputi ${ }^{4}$ self assessment terhadap pekerja sebelum melakukan pekerjaan, membuat kebijakan untuk mencegah pekerja berkumpul, membuat prosedur kerja sesuai dengan protokol kesehatan, mengatur pergantian shift kerja, waktu masuk, dan waktu istirahat untuk mengurangi jumlah pekerja di area umum, memasang media edukasi terkait pencegahan terhadap COVID-19 di tempat kerja berupa poster, leaflet dan sebagainya, dan mengadakan disinfeksi secara rutin di tempat kerja.

APD, upaya yang dapat dilakukan adalahn dengan menyediakan dan mewajibkan para pekerja untuk menggunakan alat pelindung diri selama bekerja. Alat pelindung diri yang digunakan meliputi masker, dan face shield. ${ }^{5}$

Berdasarkan upaya yang terdapat pada rekayasa teknik, maka dapat dilakukan pengembangan desain tempat kerja. Menurut Sachari dan Sunarya, ${ }^{14}$ desain adalah terjemahan fisik yang berkaitan dengan aspek sosial, ekonomi, dan tata hidup manusia, serta cerminan budaya zamannya. Sedangkan tempat kerja adalah tiap ruangan atau lapangan, tertutup atau terbuka, bergerak atau tetap, dimana tenaga kerja bekerja, atau yang sering dimasuki tenaga kerja untuk keperluan suatu usaha dan di mana terdapat sumber atau sumber-sumber bahaya. ${ }^{6}$ Dengan demikian, desain tempat kerja mengacu pada proses merancang dan mengatur tempat kerja untuk mengomptimalkan kinerja dan keselamatan pekerja. Menurut ISO/PAS 45005, ${ }^{15}$ mendesain tempat kerja dalam upaya pengendalian COVID-19 meliputi pemasangan penghalang fisik untuk menghindari kontak antar pekerja atau antar pekerja dan pengunjung, pengaturan peletakan meja, kursi kerja antar pekerja berdasarkan jarak sosial yang direkomendasikan yaitu 1,8 meter, peningkatan ventilasi, penempatan peralatan, kenyamanan termal, pemasangan tanda penunjuk jarak sosial.

\section{Tata Letak Ruang Kerja}

Menurut Marmaras \& Nathanael, ${ }^{16}$ terdapat beberapa aspek yang berkontribusi pada tata letak ruang kerja. Salah satunya dengan persyaratan ergonomis untuk menentukan ruang yang tersedia memiliki akses mudah ke pintu, jendela, dan radiator. Sedangkan desain stasiun kerja harus sesuai dengan penggunanya dan tugasnya, serta akses mudah menuju statiun kerja. Menurut ISO/PAS $45005,{ }^{15}$ tata letak ruang kerja sebagai upaya pengendailan COVID-19 dapat dilakukan dengan mengubah letak meja dan kursi kerja menjadi bersebelahan atau saling membelakangi untuk menghindari pekerja saling berhadapan.

\section{Ventilasi}

Ventilasi adalah proses pertukaran udara dengan cara mengatur agar terjadi pemasukan udara segar ke dalam ruangan dan pembuangan udara yang pengap. Hal ini dilakukan untuk menjaga kualitas udara di ruang tersebut. ${ }^{17}$ Ventilasi adalah bukaan pada dinding dan / atau atap yang berfungsi sebagai tempat masuknya cahaya dan udara alami dari luar ke dalam bangunan. ${ }^{18} \mathrm{Di}$ era normal baru, harus dipertimbangkan untuk menggunakan ventilasi alami, yaitu membuka jendela jika memungkinkan dan aman untuk dilakukan untuk meningkatkan pengenceran udara luar ruangan dari udara dalam ruangan ketika kondisi lingkungan dan persyaratan bangunan memungkinkan. ${ }^{18}$ Dalam upaya pencegahan dan pengendalian COVID-19 di tempat kerja, World Health Organization $(W H O)^{19}$ juga merekomendasikan penerapan ventilasi silang sebagai upaya dalam memaksimalkan pengembangan ventilasi. Sistem ventilasi silang terjadi akibat perbedaan tekana udara dalam ruangan oleh perletakan bukaan yang berbeda antara lubang masuk udara (inlet) dengan lubang keluar udara (outlet) ${ }^{7}$.

\section{Penghalang Fisik}

Menjaga jarak fisik yang aman selama pandemi COVID-19 sangat penting dilakukan untuk mencegah transmisi virus COVID-19 menyebar antar pekerja. Tetapi terdapat beberapa kondisi tempat kerja yang tidak memungkinkan untuk menerapkan jarak fisik. Contohnya karena keterbatasan luas tempat kerja. Sebagai alternative pengganti, maka World Health Organization (WHO), Centers for Disease Control and Prevention (CDC) dan Occupational Safety and Health Administration (OSHA) merekomendasikan pemasangan penghalang fisik atau physical barrier. Penghalang ini sering kali terbuat dari plastik akrilik (plexiglass) atau polikarbonat yang lebih ringan, lebih mudah dibentuk, dan memiliki ketahanan benturan yang jauh lebih besar dari kaca. ${ }^{20}$ Manfaat pemasangan penghalang fisik sebagai pencegahan 


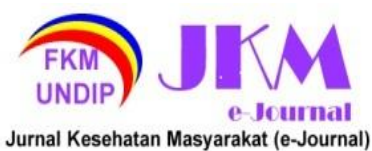

COVID-19 menurut McMaster University, ${ }^{21}$ yaitu : 1) Memisahkan secara fisik atau visual antar orang untuk mencegah kontak dan melindungi orang di kedua sisi penghalang dari droplet saat berbicara; 2) Tidak memerlukan pelatihan khusus dalam menggunakannya.

\section{Rambu/Penanda Lantai}

Jarak fisik adalah upaya menjaga jarak aman antara seseorang dengan orang lain 1-2 meter. Studi Kucharski, et al. ${ }^{22}$ menemukan bahwa penerapan isolasi diri, pengujian, dan jarak fisik akan meningkatkan kemungkinan pengendalian penularan COVID-19. Menurut ISO/PAS 45005, ${ }^{15}$ salah satu upaya dalam menerapkan jarak fisik di tempat kerja adalah dengan memasang tanda di lantai untuk menunjukkan pedoman jarak fisik yang direkomendasikan. Rambu atau penanda jarak fisik bertujuan untuk memberikan acuan kepada pekerja supaya pekerja mengetahui dimana pekerja tersebut boleh menempati suatu titik lokasi seperti berdiri dan duduk. Selain memasang tanda jarak fisik di lantai, upaya lain yang dapat dilakukan dalam menerapkan jarak fisik di tempat kerja adalah dengan menerapkan jalur satu arah di area tempat kerja seperti memisahkan jalur masuk tempat kerja dengan jalur keluar tempat kerja untuk mencegah kontak antar pekerja.

Belum ada penelitian terdahulu terkait pengembangan desain tempat kerja sebagai pengendalian COVID-19. Tujuan penelitian ini adalah untuk mengembangkan desain tempat kerja di Pos UKK Puskesmas $\mathrm{X}$ sebagai pengendalian COVID-19.

\section{METODE PENELITIAN}

Desain penelitian yang dilakukan adalah Research and Development Level 1. Fokus penelitian ini yaitu mengembangkan desain tempat kerja bersbasis engineering control sebagai pengendalian COVID-19 di Pos UKK Puskesmas X Bekasi Selatan. Sumber informasi yang digunakan pada penelitian ini adalah sumber primer yang diperoleh langsung dari informan, dan sumber informasi sekunder yang diperoleh dari dokumen Puskesmas X. Informan pada penelitian ini adalah Ketua Pos UKK dan kader Pos UKK, dan validator pada penelitian ini berjumlah 3 orang. Instrumen yang digunakan pada penelitian ini adalah human instrument, pedoman wawancara, dan angket sebagai lembar validasi. Teknik pengambilan data yang dilakukan adalah wawancara semi-struktur, observasi, dokumentasi, dan Focus Group Discussion (FGD). Teknik analisis data yang digunakan adalah reduksi data, penyajian data, dan kesimpulan.

\section{HASIL}

\section{Gambaran Umum}

Pos UKK Puskesmas X dibentuk pada tanggal 11 Agustus 2020. Karena pembentukannya yang masih baru membuat kegiatan yang dilaksanakan bekum maksimal, khususnya yang terkait dengan COVID-19. Jenis pekerjaan di Pos UKK tersebut adalah konveksi dengan jumlah pekerja sebanyak 48 pekerja.

\section{Hasil Observasi}

Hasil obervasi menunjukkan bahwa desain tempat kerja di Pos UK Puskesmas X belum sesuai dengan pengendalian COVID-19 berdasarkan ISO/PAS 45005:2020. Belum ada upaya yang berdasarkan rekayasa teknik seperti ventilasi yang memadai, tata letak ruang yang sesuai dengan pengendalian COVID-19, rambu/penanda lantai, dan penghalang fisik/physical barrier di setiap meja kerja. Padahal dalam kenyataannya, kondisi lingkungan kerja di Pos UKK tersebut kurang baik untuk masa pandemi COVID-19 saat ini. Terbatasnya luas ruang kerja membuat pekerja sulit untuk menerapkan jarak aman minimal 1 meter. Ventilasi pada area produksi dan finishing belum memadai, dan belum terdapat penghalang fisik/physical barrier di setiap meja kerja pada area administrasi, produksi, dan finishing.

\section{Hasil Wawancara}

Wawancara dilakukan guna mendapatkan informasi tambahan mengenai pengendalian COVID-19 di Pos UKK Puskesmas X Bekasi Selatan. . Berdasarkan hasil wawancara, didapatkan bahwa upaya pengendalian COVID-19 di Pos UKK tersebut belum maksimal. Hal ini dikarenakan pembentukan Pos UKK tersebut yang masih baru, sehingga belum dapat dilakukan upaya pengendalian COVID-19 lebih lanjut. Hal lain yang menyebabkan belum maksimalnya upaya pengendalian COVID-19 adalah adanya kejadian COVID-19 di Pos UKK tesebut. Terdapat 2 orang pekerja yang terpapar COVID-19 dan 1 diantaranya meninggal dunia. Hal ini menyebabkan terhentinya kegiatan kerja di Pos UKK tersebut untuk sementara. Sehingga belum ada lagi kegiatan Pos UKK dari Puskesmas X.

\section{Hasil Focus Group Discussion (FGD)}

Hasil yang diperoleh dari kegiatan FGD adalah : 1) Pemasangan penghalang fisik/physical barrier di setiap meja kerja; 2) Pemasangan rambu atau penanda lantai di tangga, dan stiker lantai berupa tanda penentu posisi pekerja berdiri.; 3) Melakukan penataan ulang letak fasilitas di tempat kerja Pos UKK seperti meja dan kursi; 4) Menerapkan ventilasi silang dan penambahan kipas angin sebagai dukungan terhadap sirkulasi udara di dalam ruang kerja. 


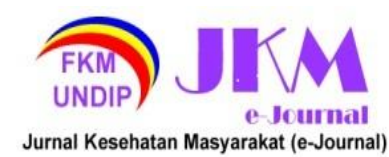

\section{Hasil Validasi}

Produk pengembangan yang dibuat oleh peneliti kemudian dinilai oleh para validator. Dengan kategori : a) Layak; b) Layak dengan sedikit perbaikan; c) Layak dengan banyak perbaikan; d) Tidak Layak.

Oleh validator I, produk pengembangan desain tempat kerja mendapat penilaian dengan kategori layak. Pengembangan terhadap tata letak ruang dinilai cukup baik, rambu atau penanda jarak fisik dinilai sudah cukup, dan pemasangan penghalang fisik/physical barrier dinilai cukup apabila penerapan jarak fisik tidak dapat maksimal. Adapun masukan yang diberikan adalah penempatan ventilasi udara yang dapat disesuaikan dengan kebutuhan para pekerja. Oleh validator II, produk pengembangan desain tempat kerja diberi penilaian dengan kategori layak dengan sedikit perbaikan. Pengembangan terhadap ventilasi, tata letak ruang, dan rambu atau penanda jarak fisik dinilai cukup baik, Adapun masukan yang diberikan adalah menambahkan lubang atau bukaan pada penghalang fisik/physical barrier di meja kerja pada bagian administrasi supaya dapat memudahkan pekerja dalam menerima dan memberikan dokumen. Oleh validator III, produk pengembangan desain tempat kerja diberi penilaian dengan kategori layak dengan sedikit perbaikan. Pengembangan terhadap
Adapun masukan yang diberikan adalah penambahan exhaust pada setiap area kerja.

\section{PEMBAHASAN}

Pengembangan desain tempat kerja dilakukan pada 3 area kerja yaitu, area administrasi, produksi, dan finishing. Pada area administrasi, pengembangan yang dilakukan meliputi: 1) Ventilasi berupa penambahan bukaan udara dan pemasangan kipas exhaust; 2) Pemasangan rambu di lantai berupa stiker bergambar silang untuk menandakan pekerja dilarang berdiri atau menempati area tersebut; 3) Pemasangan penghalang fisik/physical barrier dpada meja kerja, penghalang fisik yang dipasanga berbahan plastik akrilik dengan menydiakan lubang bukaan kecil pada area bawah penghalang yang berfungsi untuk menerima dan memberikan barang kepada pekerja lain dengan tetap terlindungi oleng penghalang.

Pada area finishing, pengembangan yang dilakukan meliputi: 1) Ventilasi, berupa penambahan lubang bukaan udara yang berjumlah 2 buah bukaan; 2) Tata letak ruang, dengan mengatur tata letak meja kerja menjadi bersebelahan dan saling membelakangi, serta mengubah letak peletakan barang atau produk jadi menjadi diletakan ke dalam Gudang sementara sebelum barang dikirim; 3) Pemasangan penghalang fisik/physical

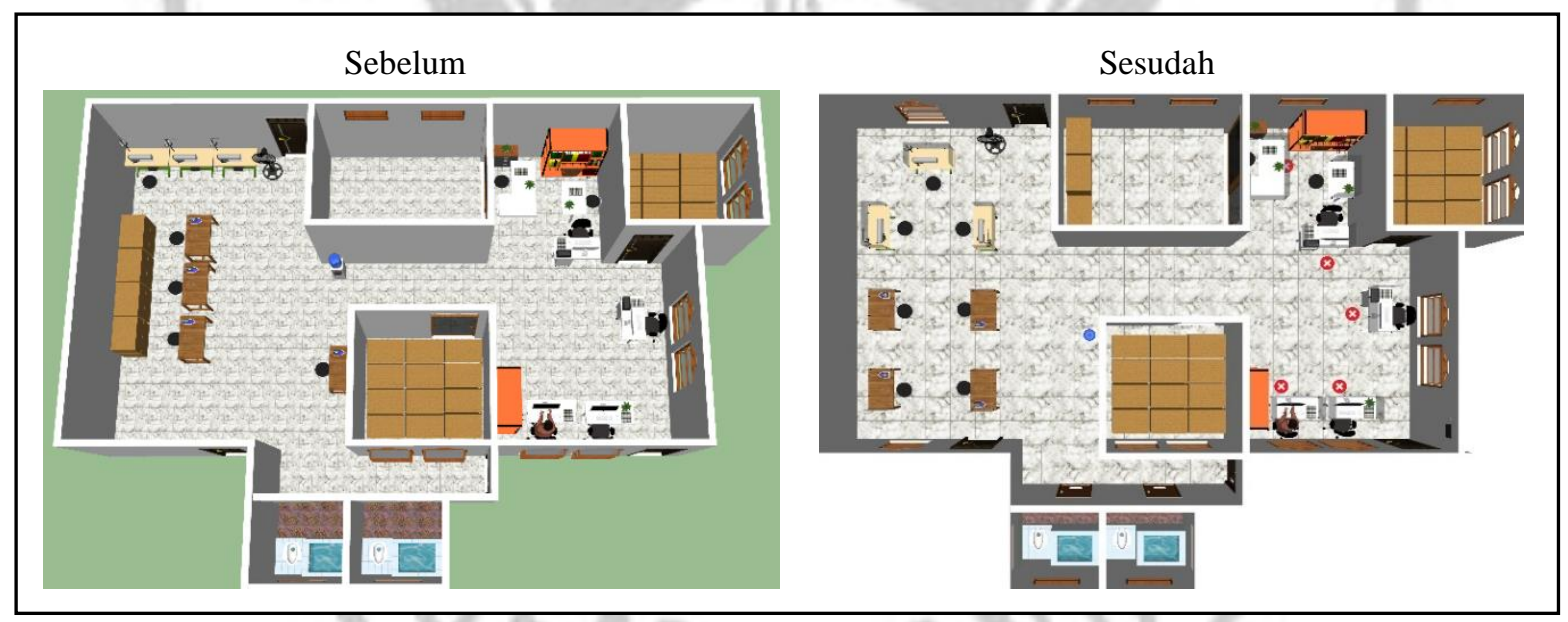

tata letak ruang,rambu atau penanda jarak fisik, dan penghalang fisik/physical barrier dinilai cukup.

\section{Gambar 1. Desain area administrasi dan finishing sebelum dan sesudah dikembangkan}

Pada area produksi, pengembangan yang dilakukan meliputi; 1) Ventilasi, berupa penambahan lubang bukaan udara berjumlah 2 bukaan, penambahan kipas angin berjumlah 2 buah, dan pemasangan kipas exhaust berjumlah 2 buah, 2) Tata letak ruang, dilakukan dengan mengubah tata letak meja dan kursi dengan memindahkan 3 buah meja dan kursi ke area depan guna mengurangi jumlah pekerja yang terdapat pada area produksi, mengubah pletakan meja-meja yang tidak terpakai ke dalam gudang; 3) Rambu/penanda lantai, berupa stiker lantai dengan gambar silang dan kaki, yang bertujuan untuk menandakan dimana pekerja harus berdiri melakukan pekerjaan guna memaksimalkan upaya jarak aman, serta dengan memasang stiker lantai di tangga yang menunjukkan arah naik dan turun guna menghindari pekerja bertabrakan saat melewati tangga (pada bagian 


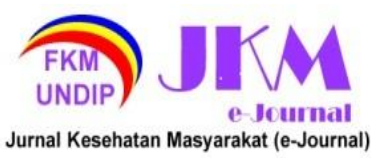

\author{
JURNAL KESEHATAN MASYARAKAT (e-Journal) \\ Volume 10, Nomor 1, Januari 2022 \\ ISSN: 2715-5617 / e-ISSN: 2356-3346 \\ http://ejournal3.undip.ac.id/index.php/ikm
}

ini juga ditambahkan pegangan tangga guna mendukung keselamatan kerja); 4) Pemasangan penghalang fisik/physical barrier pada meja kerja.

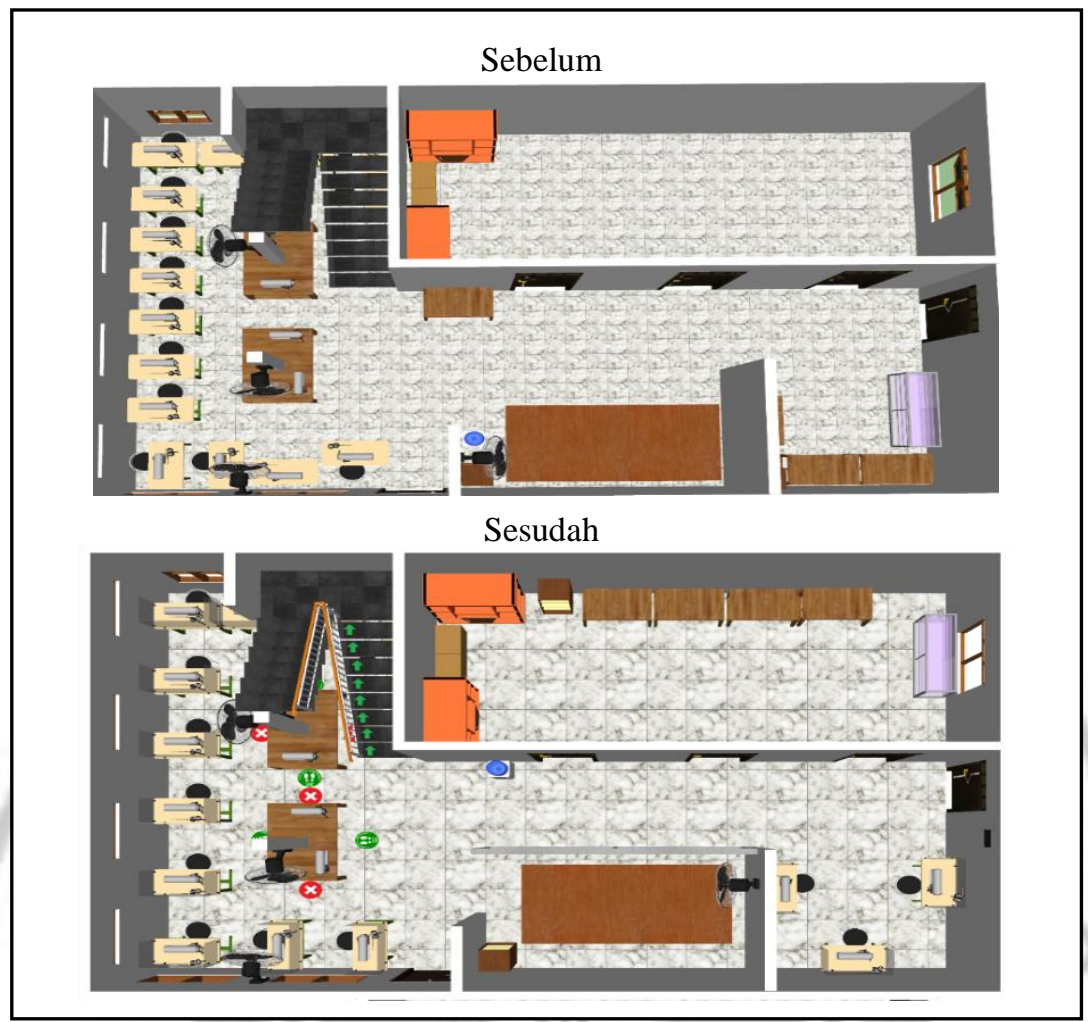

Gambar 2. Desain area produksi lantai 1 sebelun dan sesudah dikembangkan

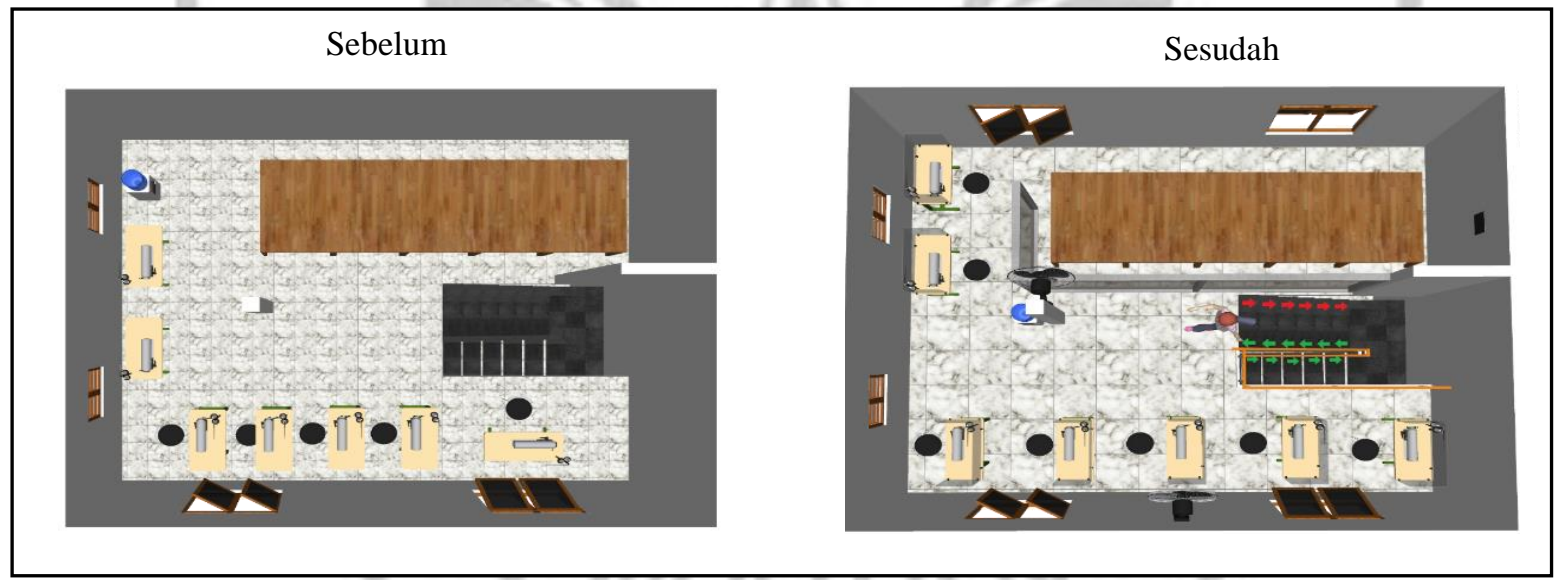

Gambar 3. Desain area produksi lantai 2 sebelum dan sesudah dikembangkan

Tata Letak Ruang Kerja

Menurut ILO ${ }^{3}$ dan ISO/PAS $45005,,^{15}$ pengaturan tata letak ruang dapat dilakukan dengan mengubah letak meja dan kursi kerja, menjadi bersebelahan dengan jarak minimal 1 meter, atau saling membelakangi untuk meminimalisir kemungkinan penularan COVID-19 melalui droplet antar pekerja. Penempatan fasilitas seperti kursi, meja, sofa, lemari, dan sebagainya diharapkan tidak mengganggu ruang bebas pekerja untuk bekerja. Persyaratan ruang area ruang kerja diperlukan untuk menghadapi COVID-19. Tata letak ruang kerja dan penempatan peralatan perlu diperhatikan agar tetap menerapkan jarak fisik. ${ }^{18}$

Ventilasi

Ventilasi mempunyai peran penting dalam mengurangi risiko penularan COVID-19 melalui pengenceran dan penghilangan partikel yang terinfeksi di lingkungan dalam ruangan. Karena salah satu cara penukaran virus COVID-19 dapat melalui udara. Virus COVID-19 tetap aktif hinga 3 jam di udara dalam ruangan dan 2-3 hari di 


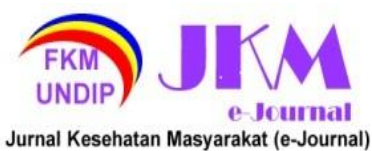

permukaan ruangan pada kondisi dalam ruangan umum. Partikel virus kecil tersebut tetap di udara dan dapat menyebar dengan dibawa oleh aliran udara di dalam ruangan atau saluran udara dari sistem ventilasi. ${ }^{7}$ Studi yang dikeluarkan oleh The National Institute for Occupational Safety and Health (NIOSH) tentang kualitas udara dalam ruangan dan menyimpulkan bahwa sumber polusi udara dalam ruangan disebabkan oleh kurangnya ventilasi (52\%), kontaminasi dari dalam gedung $(16 \%)$, kontaminasi dari luar gedung (10\%), kontaminasi mikrobiologis (5\%), kontaminasi dari material dan produk dalam gedung (4\%) serta sumber yang tidak diketahui (13\%). ${ }^{9}$

Berdasarkan penelitian yang dilakukan oleh Park, et al. ${ }^{9}$ ventilasi silang efisien dalam hal nilai pertukaran udara dibandingkan dengan ventilasi satu sisi, dan ventilasi silang direkomendasikan untuk meminimalkan kemungkinan infeksi di gedung-gedung publik dengan kepadatan tinggi. Jika ventilasi silang tidak memungkinkan, disarankan untuk menggunakan kipas tambahan untuk mencapai efek yang sama seperti ventilasi silang. Menurut $\mathrm{CDC},{ }^{23}$ kipas angin dapat digunakan untuk meningkatkan efektivitas jendela yang terbuka. Kipas angin juga dapat digunakan di dalam ruangan untuk meningkatkan pencampuran udara ruangan. Pencampuran udara ruangan yang lebih baik membantu mendistribusikan udara bersih yang dipasok dan mengencerkan konsentrasi partikel virus di seluruh ruangan.

\section{Penghalang Fisik/Physical Barrier} Berdasakan ISO/PAS 45005, ${ }^{15}$ pemasangan penghalang fisik/physical barrier diperlukan untuk memisahkan para pekerja apabila penerapan jarak fisik tidak bisa dilakukan secara maksimal. Penghalang fisik/physical barrier dapat memblokir percikan atau droplet yang dihasilkan seseorang yang berada dalam kontak dekat dengan penghalang sehingga dapat memberikan tingkat perlindungan dari kontaminasi permukaan di ruang kerja dan memberikan rasa jaminan keamanan bagi pekerja, pelanggan, dan pengunjung. ${ }^{11}$ Plexiglass atau akrilik telah digunakan sebagai bahan untuk penghalang fisik/ physical barrier antar individu dan untuk membantu menghalangi droplet ketika individu berada dalam kontak dekat. Plexyglass atau lembaran akrilik adalah nama umum untuk poli (metal metakrilat) dan merupakan termoplastik transparan yang sering digunakan sebagai alternatif untuk kaca. ${ }^{11}$

\section{Rambu/Penanda Jarak Fisik}

Karena jenis atau bidang industri di Pos UKK Puskesmas X adalah konveksi maka pekerja tidak bisa melakukan pekerjaan dari rumah karena keterbatasan peralatan yang dimiliki masing-masing pekerja. Dalam hal ini, 2 jenis jarak fisik atau physical distancing dapat diterapkkan. Jarak fisik statis mengacu pada ruang kerja fisik, terutama jarak antara karyawan saat mereka berbagi ruang kerja yang sama, misalkan kantor dan line produksi. Sedangkan jarak fisik dinamis mengacu pada gerakan karyawan ${ }^{12}$ di tempat kerja, dimana mereka harus bergerak dengan tetap menjaga jarak minimal 1 meter dari karyawan lain. Penerapan jarak fisik di tempat kerja dapat bervariasi berdasarkan jumlah karyawan dan ukuran ruang kerja ${ }^{12}$. Jarak fisik atau physical distancing dapat menghindarkan seseorang dari droplet yang keluar dari mulut atau hidung seseorang ketika berbicara, batuk, dan bersin.

Berdasarkan studi yang dilakukan oleh Kucharski, et al. ${ }^{22}$ penerapsan isolasi diri, pengujian, dan jarak fisik akan meningkatkan kemungkinan pengendalian pengendalian penularan COVDI-19.

Menurut ISO/PAS $45005,{ }^{15}$ salah satu upaya dalam menerapkan jarak fisik di tempat kerja adalah dengan memasang tanda di lantai untuk menunjukkan pedoman jarak fisik yang direkomendasikan. Tanda tersebut dapat berupa stiker panah yang menunjukan arah, tanda silang atau centang yang menunjukkan dimana seseorang diperbolehkan berdiri atau duduk.

\section{UCAPAN TERIMAKASIH}

Ucapan terimakasih penulis sampaikan kepada pihak Puskesmas X Bekasi Selatan dan Pos UKK atas izin yang diberikan untuk melakukan penelitian.

\section{KESIMPULAN}

Penelitian pengembangan desain tempat kerja berbasis engineering control sebagai upaya pengendalian COVID-19 di Pos UKK Puskesmas X Bekasi Selatan ini menghasilkan produk desain pengembangan yaitu berupa pengembangan ventilasi, tata letak ruang, penerapan jaga jarak, dan pemasangan physical barrier dengan kategori layak dengan sedikit perbaikan.

\section{DAFTAR PUSTAKA}

1. Theopilus Y, Yogasara T, Theresia C, Octavia JR. Analisis Risiko Produk Alat Pelindung Diri (APD) Pencegah Penularan COVID-19 untuk Pekerja Informal di Indonesia. J Rekayasa Sist Ind. 2020;9(2):115-34.

2 ILO. Dalam menghadapi pandemi: Memastikan Keselamatan dan Kesehatan di Tempat Kerja. Labour Adm Labour Insp Occup Saf Heal Branch Route [Internet]. 2020;1-52. Available from:

https://www.ilo.org/wcmsp5/groups/public/--asia/---ro-bangkok/---ilojakarta/documents/publication/wcms_742959.p df

3. ILO. Pencegahan dan Mitigasi COVID-19 di 


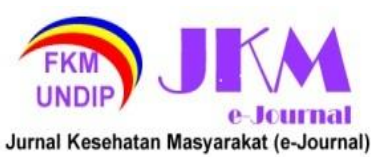

Tempat Kerja untuk Usaha Kecil Menengah ( UKM ). Int Labour Organ. 2020;41.

4. RI KK. Keputusan Menteri Kesehatan RI Nomor Hk.01.07/Menkes/328/2020 Tentang Panduan Pencegahan Dan Pengendalian Corona Virus Disease 2019 (Covid-19) Di Tempat Kerja Perkantoran Dan Industri Dalam Mendukung Keberlangsungan Usaha Pada Situasi Pandemi. Kementerian Kesehatan RI Indonesia; 2020.

5. Gugus Tugas COVID-19. Standar Alat Pelindung Diri (APD) untuk Penanganan COVID-19 di Indonesia. Jakarta; 2020.

6. Indonesia Pr. Undang-Undang Republik Indonesia Nomor 1 Tahun 1970 Tentang Keselamatan Kerja. 11970.

7. Mahardika K, Thojib J, S NSA. Sistem Ventilasi Alami pada Perancangan Pasar Ikan di Kota Pasuruan. 2014;

8. REHVA. How to operate and use building services in order to prevent the spread of the coronavirus disease (COVID-19) in workplaces. Rehva [Internet]. 2020;8. Available from: https://www.rehva.eu/activities/covid-19guidance

9. Pujianto TR, Vallery V, Soetanto C. Perancangan Kafe di Era New Normal. In 2021. p. 255.

10.Park S, Choi Y, Song D, Kyung E. Natural ventilation strategy and related issues to prevent coronavirus disease 2019 (COVID-19) airborne transmission in a school building. 2021;

11. Safety TEH and. University of Washington Guidance for Plexiglass Barriers in Support of Covid-19 Prevention Efforts Background \& Risk Reduction. 2020;1-12.

12. El Husseiny, Aly Mohamed dan El Husseiny AA. Redefining Static and Dynamic Spaces Genius integration in Historic Cairo. Asian J Behav Stud. 2018;3(9):161-71.

13. Hamouche S. Covid-19, Physical Distancing in the Workplace and Employees 'Mental Health : Implications and Insights for Organizational Interventions - Narrative Review. 2021;33(2):202-8.

14 Sachari, A. \& Sunarya, Y. Wacana Transformasi Budaya. Bandung: ITB. 2001.

15 ISO/PAS 45005. Occupational health and safety management - General guidelines for safe working during the COVID-19 pandemic. 2020. https://www.iso.org/obp/ui/\#iso:std:iso:pas:450 05:ed-1:v1:en

16 Marmaras, N. V. \& Nathanael, D. Workplace Design. 2006.

17 WHO. QA Ventilasi dan Pengaturan Suhu Udara (AC) dalam Konteks COVID-19. 2020. Available https://www.who.int/indonesia/news/novel- coronavirus/qa/qa-ventilasi-ac-konteks-covid$\underline{19}$

18 Sari, U. C. \& Budiyanti, R. T. Workplace Requirements in New Normal Era due to COVID-19 Pandemic: Design Criteria and Health Environment Perspectives. Journal of Public Health for Tropical and Coastal Region (JPHTCR). 2020;3(2).

19 WHO. Roadmap to imrpove and ensure good indoor ventilation in the context of COVID-19. 2021. Available at: https://ncceh.ca/content/blog/physical-barrierscovid-19-infection-prevention-and-controlcommercial-settings

20 Eykelbosh, A., Physical barriers for COVID-19 infection prevention and control in commercial settings.

2020.

Available

at:

https://ncceh.ca/content/blog/physical- barrierscovid-19-infection-prevention-and-controlcommercial-settings

21 McMaster University, Guidelinesfor the Use of Physical Barriers During COVID-19 Pandemic. 2020. Available at: https://hr.mcmaster.ca/app/uploads/2020/07/Us e-of-Barriers-COVID-19.pdf

22 Kucharski, A. et al., The Effect of Control Strategies to Reduce Social Mixing on Outcomes of The COVID-19 Epidemic in Wuhan, China: a modelling study. 2020;5(5).

23 CDC, Ventilation in Buildings. 2021. Available at: https://www.cdc.gov/coronavirus/2019ncov/community/ventilation.html

24 Vischer, J. \& Wifi, M., The Effect of Workplace Design on Quality of Life at Work. 2017.

25 Siregar, I., Tarigan, U. \& Nasution, T. H., Layout design in order to improve efficiency in manufacturing. 2017. s.1., s.n. 